\title{
APAD, thirty years of an intellectual adventure
} Introduction

Philippe Lavigne Delville and Alexis Roy

\section{(2) OpenEdition}

\section{Journals}

Electronic version

URL: https://journals.openedition.org/anthropodev/1357

DOI: 10.4000/anthropodev. 1357

ISSN: 2553-1719

This article is a translation of:

L'APAD, trente ans d'une aventure intellectuelle - URL : https://journals.openedition.org/anthropodev/ $1134[\mathrm{fr}]$

Publisher

Presses universitaires de Louvain

\section{Printed version}

ISBN: 978-2-39061-175-2

ISSN: 2276-2019

Electronic reference

Philippe Lavigne Delville and Alexis Roy, "APAD, thirty years of an intellectual adventure", Anthropologie \& développement [Online], Hors-série | 2021, Online since 01 December 2021, connection on 05 December 2022. URL: http://journals.openedition.org/anthropodev/1357 ; DOI: https://doi.org/ 10.4000/anthropodev.1357

This text was automatically generated on 5 December 2022

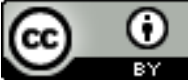

Creative Commons - Attribution 4.0 International - CC BY 4.0 https://creativecommons.org/licenses/by/4.0/ 


\title{
APAD, thirty years of an intellectual adventure
}

\author{
Introduction
}

Philippe Lavigne Delville and Alexis Roy

1 This special number of Anthropologie \& Développement marks the $30^{\text {th }}$ anniversary of our Association and its periodical. ${ }^{1}$ The $25^{\text {th }}$ anniversary gave us a chance to look back at APAD's origins and beginnings through Baptiste Albert's film, in which the founders and "historic" members were interviewed when they gathered in Niamey on the occasion of the LASDEL Summer University. ${ }^{2}$ For the $30^{\text {th }}$ anniversary, the journal's editing board has suggested launching an appeal for contributions to a special edition consisting of short articles, testimonies and reviews of its history, and spotlighting new topics. ${ }^{3}$ The objective was to offer an update on this moment in the history of the anthropology of social change and development, and to look back so as to be able to plan more effectively for the future.

2 This introduction recollects the history of APAD, its initial objectives and the structural tensions that traverse it, and introduces the articles we have been sent. ${ }^{4}$ Our historical review draws from Thomas Bierschenk's work (2009) a little more than ten years ago on the occasion of the 2007 symposium in Louvain.

\section{APAD: the Context of its Emergence and the Plan}

3 The idea for APAD emerged in the specific context of the beginning of the 1990s. "This idea must have been in the air, because the reactions of the first colleagues we consulted where immediately positive. [...] The astonishing thing was that an initiative like this had not seen the light of day earlier. After all, for many years in the panorama of Africanist research, everybody who navigated between anthropology, sociology and development felt that they had something in common and had nowhere to discuss it" (Olivier de Sardan, 1991a). By taking this look back at prehistory, we can explain this spirit of the times, and also highlight some of the early roots and spaces of the debate that have been somewhat forgotten in the "official history" of APAD. From a 
"development" point of view, the 1980s were a turning point. Structural adjustment and criticism of States led to the State being questioned, and the local being (over)rated. Criticism of the major state and technocratic projects of the 1960s and 1970s was also shared by social science researchers, members of NGOs and the aid institutions themselves: having supported State modernisation projects for twenty years, they now described the State as corrupt and inefficient, halted or renegotiated their structural support for regional development and planning entities, and in turn once again (Chauveau, 1994), and in any event in the discourse - promoted small projects and participation in and support for local organisations. Modernisation and remedial theories were questioned, and the approaches to research and development in agriculture (Khon Kaen, 1987; Pillot, 1988) and participation (Chambers et al., 1989) prompted reflections among social science researchers and development practitioners.

This "discovery" of the local environment and popular initiatives drew on the work of social sciences in the previous decades, which had placed the emphasis on peasant know-how and the rationality of peasant practices, which were anchored in ecosystems and had the objective of minimising the risks in random environments, in contrast revealing the normative character of the technical proposals emanating from research and development, which was frequently poorly adapted to the local context. The 1978 Ouagadougou seminar "Mastering Agrarian Space and Development in Tropical Africa. Peasant Logic and Technical Rationality" (CNRST and ORSTOM, 1979) was a landmark moment in the case of Africa. Through a rediscovery of the results of seminal works (Dumont, 1935; de Schlippe, 1956) and the dynamics of peasant agriculture (Richards, 1985), agricultural research and development developed methods for co-constructing innovations with peasant farmers. Through this discovery of the rationality of peasant practices, with the accent on support for local initiatives through aid, it seemed possible to make less "heteronomous" development interventions, and space opened up for collaborations between researchers and practitioners in a context in which, as part of the participatory methods, technicians were supposed to place themselves at the service of local communities, which were often largely idealised. The appeal from anthropologists for improved knowledge of societies also struck a chord.

5 Anthropology also went through some changes. Albeit with powerful differences in national histories, "classical" anthropology still dominated academic training, but dynamist concepts that sought to take account of the contemporary dynamics of social change, in the context of a Georges Balandier acknowledging the "colonial situation", were in the process of imposing themselves. These perspectives of a dynamic political anthropology anchored in empirical work also contrasted sharply with Marxist economic anthropology, which, while fundamentally posing the question of the transformations of societies influenced by penetration by merchant relations, brought with it a somewhat empirically limited concept of "development" (Copans, 2009b). Works that adopted a historical perspective questioned colonial and post-colonial policies (see, for example, Chauveau et al., 1981; Chauveau, 1982a). The anti-imperialist criticism of development (Copans, 1975) was called into question by empirical research that placed the complex interactions and responsibilities of national bourgeoisies front and centre (Olivier [de Sardan], 1975; Amselle and Grégoire, 1987). Development projects and "development" emerged as focuses of interest, most frequently on the part of researchers with a direct or indirect association with the development milieu, on 
occasion as the subject of a fundamental anthropology and a space for dialogue among practitioners.

6 To be more precise, in Europe ${ }^{5}$, in the 1980s alone, three movements in development anthropology developed alongside each other in different European countries, and symposiums and seminars were held that enabled exchanges, and in some way formed the conceptual and relational foundations on which APAD was founded.

7 One of these was associated with the School of Development Sociology in Wageningen in the Netherlands, around the figure of Norman Long. In the 1970s, Long first proposed a dynamic sociology of development (Long, 1977), starting mainly from Latin American countries. The notion of interface and confrontation between peasant knowledge and technicians lay at the heart of his research (Long, 1989; Long and Long, 1992), and had a major influence on APAD's investigations. Norman Long was invited to give the inaugural lecture at APAD's symposium in Bamako in 1984. Certain of his pupils, Geert Diemer and Roch Mongbo, have also been members of the Association's board.

8 The second movement was based in Germany. As Thomas Bierschenk explains in this issue, "development" played a major role in the modernisation of the discipline, which had long been trapped far from the modern world and cut off from international networks. The controversial creation of a working group on the anthropology of development in 1985 marked the commitment of young anthropologists to the subject. But it was at the University of Bielefeld and the Free University of Berlin, led by Georg Elwert and Hans-Dieter Evers, that the path to an empirical anthropology of development was laid out, and the outcome of this was the notion of the strategic group (Evers and Schiel, 1988) and of development as an "intervention in dynamic systems" (Elwert and Bierschenk, 1988). The famous special number of Sociologia Ruralis (Bierschenk and Elwert, 1988) included contributions by J.L. Amselle and J.P. Olivier de Sardan.

9 Finally, in France, ORSTOM (which is currently undergoing institutional transformation: see J.-P. Chauveau and J.-P. Dozon in this number) conducted multidisciplinary reflections on development in the 1980s (Aubertin et al., 1982 a and b; Couty et al., 1983, 1985). These consisted of an "interdisciplinary maturation of a diversified anthropology of development" (J.-P.Chauveau, in this volume), and proposed a research programme that highlighted the importance of the historical perspective, the mistakes made by colonial and state policies and the uncertainties surrounding their ability to attain their objectives, and finally, the importance of the resistance strategies of local societies (Aubertin et al., 1982b. The development projects had been the subject of a previous study (Dozon, 1979). In particular, J.-P. Chauveau made the case for a historical sociology of development, taking up Augé's postulate (1972), according to which "the only possible sociological purpose of a study of this socalled development action is the action itself and its modalities, the complex ensemble made up of the "developers" and the "developed" (emphasis by J.-P. Chauveau), all while stressing the diverse nature of these two categories, and he proposed a definition that has become canonical: "Logic dictates that there is development where there are developers, where specialised actors aligning themselves for development have the authority to intervene in communities 'to be developed'" (Chauveau, 1982b: 16-17). This research by ORSTOM had the support of a number of training sessions for those working with them (Boiral et al., 1985) and seminars that brought together researchers 
and practitioners (Olivier de Sardan and Paquot, 1991). The issues of analytical categories and investigation methods, with the AMIRA ${ }^{6}$ group, were also a topic of dialogue, both interdisciplinary and with practitioners.

It was by using exchanges and collaborations that various meetings and seminars made it possible to develop among these three stories that APAD was founded on the initiative of Jean-Pierre Olivier de Sardan and a small group of European and African colleagues working in these networks (especially Jean-Pierre Chauveau and Thomas Bierschenk), at the crossroads of three objectives (Anonymous, 1991):

- to make social change and development a legitimate field of research in anthropology and an opportunity to rejuvenate the subject (Olivier de Sardan, 1991b). In the first place, this meant making a final break with "our grandfathers' anthropology", which was still being taught at the time, in favour of a dynamic approach along the lines suggested by Balandier, and then to acknowledge the place of "development" in the everyday realities of African societies: "The processes of social change and development provide anthropology with new purposes and new questions. From there, they can contribute towards partially revitalising issues relating not only to anthropology, but through it to the social sciences as well";

- to promote a constructive dialogue with development actors so as to reduce the most important disparities in interventions by means of the circulation of information and collaborations;

- to revise training in anthropology, especially in Africa, thereby opening up new prospects for young anthropologists outside academia.

11 APAD was therefore founded on the basis of four powerful assumptions (Olivier de Sardan, 1991a):

- the treatment of 'development' as a specific form of social change driven from outside: "In effect, it had to be made clear on the one hand, that 'development' is no more than a particular historical form of social change, and on the other, that we also intend to focus on the transformation processes and social dynamics that take place 'outside development'";

- an open approach to anthropology: "The reference to anthropology in APAD's name must be interpreted as a concern shared by all its members, whatever their 'specialisms' may be, to draw attention to the social representations and logics of all social actors involved in the social change and development. This implies certain forms of attention, listening, analysis and skill that fall within an anthropological approach without being a monopoly of anthropologists - far from it";

- rejection of a split between fundamental and applied anthropology: "The founding direction was clear from the beginning: we intended to combine a fundamentalist anthropology that took 'development' as a subject of study and an 'applied' anthropology associated with 'development' actions. We were aware that there might be a contradiction between these two poles, that some would pull towards the former and the rest towards the latter, that some people would reject the 'practical' function and that the theoretical function would scare away others. However, this was a necessary tension, in our opinion, one that might be productive. We still believe this to be true, and to some extent, APAD is based on this tension";

- and finally, "this original and decisive concept of a 'Euro-African' association [...]. APAD's initial success, despite a massive French presence because of this earlier history, was that it succeeded in giving a true 'Euro-African' dimension to its founding days. APAD's first task will be to develop this dimension as much and as quickly as possible over the course of its 
history. An effective presence and APAD's activities in Africa itself will be the clearest sign of this".

The success of the first meeting, which brought together more than 80 people on 5 and 6 March 1991, bore witness to the interest this initiative had aroused. Subsequently, in a more or less makeshift fashion and with varying degrees of success, APAD attempted to contribute towards these objectives and to maintain these assumptions.

Originally based around an analysis of the role of actors in the local interfaces between social spaces and external interventions, the anthropology of development has expanded its range of investigations over the course of the years. Moving its objectives horizontally, the socio-anthropology of development became a socio-anthropology of African public and collective administrations and services (Olivier de Sardan, 2007), and moving vertically, it became a socio-anthropology of global social engineering (Bierschenk, 2014) that contributed to an anthropology of public action in the context of aid (Lavigne Delville, 2016) and globalisation (Copans, 2009a, 2016) ${ }^{7}$. After 15 symposiums, around 20 volumes, 51 issues of its bulletin (and later journal), the scientific assessment is extremely clear. APAD's perspectives have spread widely. Without setting a precedent in the true sense of the word, APAD has made a powerful contribution to the development of a field of study of anthropology in its own right, and has also contributed to its reshaping, beginning from the margins (see Bierschenk in this issue). But more generally, it has also conveyed and spread a certain way of producing knowledge about contemporary Africa by fostering in-depth empirical analyses.

\section{Initial Tensions and their Future: An Attempt at Self- Sociology ${ }^{8}$}

The Association was designed from the start to be a dynamic collective, and it has never belonged to an individual or a group. The fact that its initiator and first Chair, JeanPierre Olivier de Sardan, passed the baton at a very early stage also contributed to this dynamic, which was reinforced by an original institutional grounding that Jean-Pierre theorised at the time as "the cuckoo strategy": far from being structurally tied to a laboratory and the risk that it might become a part of it, APAD was conceived to be temporarily hosted in a laboratory that would offer it institutional anchoring and support for a certain amount of time until another team, in a different laboratory in a different country, took over. The secretariate was therefore in Montpellier, Marseille, Stuttgart, Marseille, Leiden (with an abortive attempt to transfer it to Niamey) and Uppsala, before it returned Montpellier. It is scheduled to move to Louvain in 2022. From the outset, the founders encouraged an original dynamic for an academic association in which young people had a place $^{9}$, relations were relatively nonhierarchical and conviviality was not a hindrance to academic rigour. It was a place where participation in the Association was based on intellectual interest, and for the members of the board it a voluntary investment of time, with no financial or careerrelated stake. The Association has thus always refused to steer research projects directly, for example, in order to avoid access to funding that would involve competition among its members. It was through collective research projects piloted by Jean-Pierre and colleagues (Thomas Bierschenk, Giorgio Blundo), but supported by their academic institutions and not APAD, that work was done on the first major topics 
tackled in the association's symposia and publications (such as brokerage, corruption and health).

APAD's small initial network, which was largely based around inter-knowledge, has developed very considerably in thirty years. A number of members have remained loyal until today, in some cases since the Association was founded. Others were just passing through. The membership has changed over the course of time. Some members have died (Mathieu Hilgers, Bréhima Kassibo and Hadiza Moussa), sometimes far too young, but in the words of Georges Brassens, "Never, absolutely never, did the hole in the water close over them". What started out as a small kernel, strengthened by the regular encounters made possible by the symposia, together with research projects that brought this nucleus together, gradually became a wider - but also looser - network in which members came together on the occasion of a seminar or for a topic without necessarily making a long-term commitment. APAD's ideas spread far and wide, making its academic position less original, while "development" as a purpose eroded.

To listen to feedback from participants at seminars, however, APAD remains a profoundly original space, one one that allows in-depth exchanges in a relaxed environment, and one in which the founding promises are still structuring, albeit to varying degrees.

\title{
"Development" as a theoretical ambition
}

\begin{abstract}
"In order to take account of the dominant classes - whose role is increasingly being put in the spotlight by recent research (for example, Bayart) - one needs to consider that they owe their political survival, at least partially and indirectly, to aid for development. This aid does not only secure the possibility of "autonomisation" for this class (which is also seeing rapid expansion. It is an essential factor when it comes to implanting and rooting a clientelist logic in social relations within this same class, and then between the State and peoples: at all levels of African societies today, we can define "development" in terms of ripples of transfers of funds (by countries and multilateral institutions that donate money to African governments more than the transfers to populations). As a result of this, the projects financed by aid to development make a fundamental contribution to the legitimisation of African regimes. [...] For its part, development aid seems to be the field of a practice on to which a number of different principles of social organisation, action logics and forms of discourse are superimposed in a particularly direct way." (Bierschenk, 1991)
\end{abstract}

Questions and key concepts are put forward from the time of the texts outlining the programmes: development is a part of everyday life: it plays a role in legitimising States and reproducing elites, it plays an economic role that in some ways resembles the oil economy, and it generates financing chains and brokerage logics - as suggested by C. Lentz (1988) - that contribute towards the bureaucratisation of societies.

While works on the comparisons among various forms of know-how have placed the accent on relations between technicians and peasants, the setting here is clearly one of political anthropology. Making 'development' a legitimate topic of socioanthropological research and encouraging solid empirical investigations around this subject are objectives that we can consider to have been achieved. Empirical research has multiplied over the past thirty years, both within and outside the APAD network. The most significant results of APAD's research have spread widely, and have been taken up by geographers and political scientists, among others. The research fields 
have developed and expanded towards the aid institutions themselves. However, it is also possible to think that there has been an equal, if not even more marked, level of success in both neighbouring disciplines and anthropology itself, at least in France, although on the initiative of APAD members and above all other anthropologists such as Laetitia Atlani-Duault, questions of humanitarian aid and development have been admitted to the most classic of anthropological circles, such as the Society of Ethnology (Atlani-Duault, 2005) and Ethnologie Française (Atlani-Duault, 2011). APAD has also made a major contribution to offering quite an extensive vision of "development", one that significantly expands the study of projects, aid institutions and "beneficiaries". This reflects an ambition that is clear from its title (but is sometimes relegated to the common representations of the Association): the study of 'social change' and the ties between social change and planned interventions, whether they be State-run or associated with development or humanitarian aid.

APAD is not the only group engaged in this dynamic. Another more academic network, one that is more focused on Asia, the EIDOS network (the European Inter-University Development Opportunities Study Group), has made an equally important contribution (see Thomas Bierschenk in this special number, which this paragraph refers to extensively). Founded in 1985 by Philip Quarles Van Ufford (Amsterdam), Hans-Dieter Evers (Bielefeld) and Mark Hobart (SOAS London), and revived in the 2000s, especially by David Mosse (SOAS London) and David Lewis (LSE London), this "relatively small informal network of European anthropologist from the Netherlands, the United Kingdom and Germany" (Bierschenk) held 10 conferences between 1985 and 2008, and has produced a number of reference works (Hobart, 1993; Quarles Van Ufford and Kumar Giri, 2003; Mosse, 2005; Mosse and Lewis, 2005; Lewis and Mosse, 2006; and Mosse, 2011).

The notion of brokerage, which was initially developed on the initiative of members of APAD's founding group (Bierschenk et al., 2000), was taken up by EIDOS and applied all along the aid chain, and not only at local interfaces (Lewis and Mosse, 2006). David Mosse's contributions to the project study (Mosse, 2005) was integrated into APAD's research. However, between EIDOS and APAD, essentially, in all likelihood, because of language issues, and perhaps also geographical area, there have been - and this might be a subject of regret - more parallel trajectories starting from the same epistemic basis with some reciprocal borrowing, than real dialogue, despite the fact that a number of APAD members have taken part in EIDOS's conferences. There is no doubt that due to the fact that Anglo-Saxon anthropology has a greater connection with aid expertise and funding, EIDOS's work investigated the aid worlds (Lewis and Mosse, 2006; Mosse, 2011) more extensively and earlier than that of APAD, which was centred more around domestic institutions (Olivier de Sardan, 2007; Lavigne Delville, 2016) (Bierschenk, in this number).

While APAD has successfully legitimised 'development' as a topic, demonstrated the importance of practice beyond discourse and promoted empirical works, its brand of socio-anthropology has never become institutionalised in a specific laboratory, a highly positive achievement! In line with the desire to articulate social change and planned interventions, "development" has rarely been the sole, central theme of the work of those who have made major contributions to it. Its dimension as a network spread among multiple institutions has remained strong. Is this broad, widespread appropriation not a better indicator of success than being captured within a clearly- 
identified school? The APAD network itself exists outside the Association. The European Doctoral School for the Anthropology of Development and Social Dynamics, which has just completed its $13^{\text {th }}$ edition (Uppsala, September 2021) clearly emerged from this seed. It is facilitated by current or former APAD members, and is often described as the "APAD Doctoral School" without being officially labelled as such (which has made it possible to integrate it into the Association's activities and promote it through its intermediary without taking anything away from its independence).

\section{A constructive dialogue between researchers and practitioners}

\footnotetext{
"Development institutions do not always have the scientific resources to take the dynamics of the societies they wish to transform into account or understand the social processes involved in the transformations that are under way (as a part of development actions, as well as outside them). We want to promote anthropology as a partner that can make a positive contribution so that development operators provide quality services to the people to whom they are addressed. For this purpose, we must kindle more satisfactory forms of collaboration between anthropologists and researchers or experts from other disciplines." (Anonymous, 1991)
}

Dialogue with practitioners was a second central premise. The debate on applied anthropology is as old as the subject itself (Malinowski, 1929; Evans-Pritchard, 1946; Mair, 1971), but the context of the 1980s gave it a new shape. APAD rejected the break between an applied, strictly operational 'development anthropology' at the service of projects and an 'anthropology of development' as a critical academic discipline that had 'development' as its object. In order to be relevant, applied anthropology must rely on a fundamental anthropology of development (Olivier de Sardan, 1995), and in return, the latter is enriched by having to confront practice, thereby constituting an original form of "anthropology of development based on anthropology in development" (Crewe and Axelby, 2013: 40, cited by Thomas Bierschenk in this number $)^{10}$. Seminars and training have been organised within APAD, and research has been arranged with aid agencies and projects. The 2010 Ouagadougou symposium was dedicated to the question of engagement and application (Hagberg and Ouattara, 2012) (see also Hagberg and Widmark, 2009). APAD's work is used in training and master's degrees in cooperation, and numerous practitioners have become familiar with it. More than 12,000 copies of Jean-Pierre Olivier de Sardan's reference work Anthropologie et Développement have been published in French, a record in the human sciences, and evidence of an audience that goes far beyond academic environments.

The community premise that was idealised in the 1990s has become broadly outdated in the aid world, and for some time now it has been common practice to talk of actor strategies. Social scientists are now recruited more frequently in the aid world, even though they remain on the margins. While APAD certainly does not wish to claim to play a major role here, it has a real influence in this field, although this does not translate to any great degree into practitioners becoming members of APAD, and even less to their making contributions to the journal.

Similarly, this influence as only partially translated into collaborations. The problems of the "missing link" (Olivier de Sardan, 2004; Lavigne Delville, 2007) remain, especially the difficulties with mutually acknowledging other people's professions and know-how, and the time lag between research and action, despite the fact that proven skills have been stabilised (Vidal, 2009). Additionally, the spaces for innovation within the aid 
worlds have been reduced even further, and the critical dimension of socioanthropological work are now even less acceptable because the methods for implementing aid have become far more bureaucratic in recent decades (Lavigne Delville, 2012). The "desire to improve" described by T.M. Li $(2007 ; 2020)$ is increasingly being reduced to the application of standardised models (Olivier de Sardan, 2021) that seek to control the political and social risks, where recognition of the logics of actors from below and the response to their priorities are becoming even more secondary than before. Unfortunately, developments in global aid logics have closed the spaces for collaboration that opened in the 1990s rather than exploring them.

The importance of the questions APAD poses is not an issue, however, and nor is the value of training practitioners in the human sciences. These practitioners have limited margins for manoeuvre because of their institutional status (Mathieu, 2012; Reikat, 2012), however, and they need critical works by researchers in order to be able to take a step back from their intervention contexts and give legitimacy to their analyses (Mathieu, 2012). While their ability to influence schools of thought and modalities of action is better than non-existent, it remains extremely limited (Fresia, 2018).

\section{A desire for a balanced dialogue between members from the "North" and from the "South"}

From the very beginning, APAD's founders wanted the Association to bring together European and African researchers who shared the same problems by mobilising existing networks and partnerships. This was a major policy position (and it is an original one compared, for example, to that of EIDOS, which did not have this ambition), and it translated into a number of early decisions: an active policy of mobilisation within the board, low subscriptions, symposium registration costs that are broadly lower than average and the decision to organise symposiums in Europe and Africa alternately so as to compensate for the practical difficulties (such as budgets and visas) affecting participation by African researchers in academic events organised in the North. The symposium budget has therefore systematically included responsibility for a certain number of trips by African colleagues who do not have a budget and by students, which has made it possible to invite between 15 and 25 people, depending on the year and the available resources.

Ever since it has been possible to put journals online, the ambition to make written materials accessible to everyone has also resulted in the publication of the Bulletin on OpenEdition free of charge since 2007, in particular thanks to Jacky Bouju's commitment. The decision to use OpenEdition rather than a paid channel such as Cairn was repeated for the same reasons when the Bulletin became a journal, which deprived the Association of an opportunity to partially self-finance it.

We should note that this policy was designed above all to reduce barriers to access and encourage wide involvement, whatever the geographical location and the possibility of using institutional resources might be. The reduced membership rate is therefore calculated as a function of income level and not geographical location or origin: a lecturer-researcher from an African University who has a stable post and income from consultancy pays the full rate. The travel costs the Association absorbs at the time of symposiums also involve European doctoral students in a secondary way. This is a response to a pragmatic realisation that it is practically impossible to establish 
categories (would they be based on origin, or institutional anchoring, or place of residence?), and above all to an express desire not to demonstrate the differences between categories of members by institutionalising them.

Thirty years on, we can take the position that our initial ambition has been partially realised. APAD is without question one of those rare International academic associations whose membership is relatively balanced. The participation of African colleagues on the board, whether they are based in Africa or Europe, has been a constant (they include Séverin Abega, Sylvie Ayimpam, Nassirou Bako-Arifari, Elieth Eyebiyi, Abdou Salam Fall - APAD's only African president -, Bréhima Kassibo, Ludovic Kibora, Félix Koné, Roch Mongbo, Fatoumata Ouattara, Hamani Oumarou and Mahamane Tidjani Alou), with contributions that are sometimes marked by communication issues and the particular constraints of research and teaching in Africa, where student numbers, salary levels and redistribution obligations make investment in associative dynamics even more expensive in terms of opportunity costs than in Europe.

It should be noted, however, that although the European dimension is a real one (in particular as regards Northern Europe), African participation remains very strongly centred around West Africa, followed by Francophone Central Africa. The long-desired expansion of the English-speaking contribution has only partially been realised: the great majority of the members from Northern European countries work in Francophone Africa, and only a few researchers working in English-speaking areas of Africa are members of the Association. The English area is present in APAD's life, but it remains of secondary importance.

\section{An Africanist association that encourages young researchers or theme-based association on "development"}

31 A tension has gradually developed between an Africanist association aimed at encouraging young researchers and a theme-based association. This tension crystallised in the mid-2000s at the time Giorgio Blundo and Jacky Bouju were considering replacing the Bulletin with an academic journal - to be called Arenae - that would contain studies on APAD's topics, whatever the geographical area might be, and a collection of APAD's working documents, with easier access. This project was challenged by others, in particular Mirjan De Bruijn, who was the general secretary at the time, on the grounds that APAD was, and needed to remain, above all an association centred around African social sciences research, and that the creation of an international-level journal such as this risked marginalising African colleagues, as APAD lacked the resources to simultaneously support a journal and a collection of working documents, which also brought with it the risk of having two separate tiers of publications.

32 This journal project never saw the light of day. Under the aegis of Sten Hagberg, the Bulletin gradually moved towards functioning as an academic journal (with an editorial board, etc.) without, however, erecting excessively difficult barriers to access by authors who had less experience of scientific writing. It is possible to take the position that the transformation of the Bulletin into a journal in 2013, and the subsequent elimination of the words "Euro-African" from the Association's name at the time of the 2015 general meeting in Cotonou ${ }^{11}$ finally led to a "gentle" transition: Anthropologie \& 
Développement is an international academic journal that sets out to be accessible to authors with less experience in international publishing, and is located in the specific field of the links between social change and voluntary interventions, while remaining very much, but not exclusively, centred around Africa (articles have been published on Vietnam, Cambodia, Bolivia, etc.).

\section{Women's space in the Association and its research work}

Although it was not a part of the initial premises, the question of women's space in APAD merits reflection. APAD was born at a time when the gender issue was not yet on the agenda, in France at any rate, and it followed the evolution of research and its feminisation. Women have been members of the Association, and members of its board as well, since its foundation or shortly thereafter (they include Yasmine Marzouk, Doris Bonnet, Elisabeth Paquot and Gudrun Lachenmann). However, access to positions of responsibility came later, and first, as is often the case, with support functions general secretariat and treasury (Mirjam De Bruijn, Marilou Mathieu, Pascale Maïzi and Laurence Boutinot) - and with the creation of the editorial board (Fatoumata Ouattara and Gabriella Körling). This highly "male" history was revealed in an especially brutal fashion when the film of the history of APAD made for the Association's $25^{\text {th }}$ anniversary was first viewed. Although the list of people to be interviewed had been approved at a board meeting, the female members of the board were shocked when they saw the first cut, and were faced with what appeared to be extremely maleoriented picture of the Association. What was broadly a historical reality was partly the product of the history of the filming process ${ }^{12}$, but it obscured women's participation in the board and the role some had played since "ancient times". As was the case in the research milieu, the situation evolved significantly in the direction of feminisation. Today, the board is made up of 12 women and 6 men (but it does not have any female researchers from African research institutes or universities), and the editorial board of Anthropologie \& Développement consists of 11 women and $5 \mathrm{men}$, a trend that is assuredly not about to be reversed!

There can be no doubt that in line with this history and the Association's Frenchspeaking roots, the question of gender has only been tackled belatedly and partially in APAD's work. Only one dossier of four articles has been dedicated to it - in 2000 - under the direction of Danielle de Lame (2000), following a critical article on the 1995 Beijing conference, where the "gender and development" approach was adopted (Mathieu, 1996). It cannot be said that APAD has truly followed - and even less accompanied or anticipated! - the evolution of the issue, and we will return to this below. It is even more astonishing that as far as the aid world and practitioners are concerned, the "gender and development" approach is an old refrain. Undoubtedly, some APAD members - including a number of women! -were resistant to what might have seemed to be a 'fashion' among funders, and to what were only slightly anthropology-oriented guidelines. Studies on gender-based social relations have largely been developed outside the APAD network, and they have only partially percolated into the Association. 


\section{Conclusion: APAD in "post-development"}

As we look back over these thirty years, we can emphasise a number of paradoxes in the current situation. The approaches APAD, has taken, as well as all those that have been developed in adjacent perspectives, whether independently or not, seem to have been largely in an academic framework, most assuredly without being hegemonic, which in any event was never an ambition. But at the same time, what has "development", the anthropology of development become as the field?

Ultimately, with structural adjustments, there is the idea of progress that has been eroded. "Development" has partially lost its progressive ambition as regards both its modernising and emancipating dimension. The machinery of development has been strengthened and bureaucratised, at a cost of significant loss of direction. "Project" have been partly marginalised in favour of global policies and extremely vague watchwords, alongside the rise of topics associated with the fears of industrialised countries, such as migration and insecurity. 'Development' as an ideology has virtually disappeared in favour of global policies co-produced within the asymmetrical relations between international and national institutions that codify forms of limited sovereignty (Risse, 2013; Fresia and Lavigne Delville, 2018b).

had consequences for the anthropology 'of development'. We have already noted the fact that it has become largely an anthropology of global social engineering. Following a period of emulation and the emergence of new notions that flourished far outside it (brokers, arenas, practical rules, etc.), it seems to have developed according to ongoing logics of openness and extension, finally reaching all actors and levels of development, followed by public policies and finally all processes of social change. As Thomas Bierschenk emphasises (in this number) in the case of Germany - and one might undoubtedly also make a generalisation here - the "development" label has largely disappeared from students' research topics, but neither the purposes nor the questions posed of these purposes have: international institutions, global policies and how they are translated or interpreted locally, etc.

"development" field, as well as the academic world, we would like to reaffirm the importance of studies with a high degree of empirical density on the current forms of societal governance at its various levels, as well as the initial, and still pertinent, values of APAD in the face of the neoliberal steamroller by remaining attentive to the question of hierarchical relations in the academic world and beyond, between the "North" and the "South", among generations, between researchers and practitioners, etc. How can the specific aspects of APAD's approach be reformulated if its purpose is expanding, at the risk of becoming diluted? What challenges, what aims and what working methods must APAD adopt in the coming years?

These questions are answered in the article in this issue by Sarah Fichtner and Anneke Newman. Is it that the institutionalisation, "routinisation" and academic normalisation of APAD were inevitable with age, and have meant that it has lost its flavour? As the Association consolidated its position, it may have been caught up in logics that weaken its initial ambitions: the search for funding, a cumbersome bureaucracy, or a narrower academic world, for example. In particular, they call on us to revive the ambition to include men and women who practice applied anthropology in the development world, as well as engaged anthropology. 
The increasingly precarious position of research in Europe also raises questions regarding the conditions for engagement in the dynamics of associations that are not the most effective of academic benefits, whatever their interest may be.

41 At a time when the baton is being passed on to a new generation, we probably also need to be more courageous, and to renew our practices, so that we do not become stuck with a seminar/publications refrain. In response to the multiple dynamics that led to APAD's creation, this is a stated, multifaceted position that we must continue to assert in scientific and institutional, as well as policy planning. It requires significant mobilisation, and probably growing strengths. The door is wide open! The APAD of tomorrow will be what the young researchers make of it.

\section{BIBLIOGRAPHY}

Amselle J.-L., Grégoire E., 1987, “Complicités et Conflits entre Bourgeoisies d'État et Bourgeoisies d'Affaires: au Mali et au Niger", in E. Terray (ed.), L'État Contemporain en Afrique, Paris, L'Harmattan, pp. 23-47.

Anonyme, 1991, "Pourquoi une "Association Euro-Africaine pour l'Anthropologie du Changement Social et du Développement"?", Bulletin de l'APAD, no. 1, https://journals.openedition.org/apad/ 327 (accessed on 17 August 2021).

Atlani-Duault L., 2005, Au Bonheur des Autres. Anthropologie de l'Aide Humanitaire, Nanterre, Société d'Ethnologie.

Atlani-Duault L. (ed.), 2011, Ethnographies de l'Aide, Coll. Ethnologie Française vol. 41, PUF.

Aubertin C., Cabanes R., Chauveau J.-P. et al., 1982a, “Où Il Est Dit que le Développement Est un Objet Historique”, Revue Tiers Monde, no. 23(90), pp. 297-305.

Aubertin C., Cabanes R., Chauveau J.-P. et al., 1982b, “Esquisse d'un Programme”, Revue Tiers Monde, no. 23(90), pp. 335-344.

Augé M., 1972, “Sous-Développement et Développement: Terrain d'Étude et Objets d'Action en Afrique Francophone", Africa, no. 42(3), pp. 205-216.

Bierschenk T., 1991, "Les Projets et les Politiques de Développement Sont-Ils des Préoccupations Légitimes de l'Anthropologie?”, Bulletin de l'APAD, no. 1, https://doi.org/10.4000/apad.286

Bierschenk T., 2009, "Anthropologie et Développement; Historiciser et Localiser les Approches", Bulletin de l'APAD, no. 31-32, pp. 161-192.

Bierschenk T., 2014, "From the Anthropology of Development to the Anthropology of Global Social Engineering", Zeitschrift für Ethnologie, no. 139(1), pp. 73-97.

Bierschenk T., Chauveau J.-P., Olivier de Sardan J.-P., 2000, Courtiers en Développement: les Villages Africains en Quête de Projets, Paris, APAD, Karthala.

Bierschenk T., Elwert G. (eds.), 1988, “Aid and Development”, Sociologia Ruralis, no. 28. 
Bierschenk T., Olivier de Sardan J.-P. (eds.), 2014, States at Work. Dynamics of African Bureaucracies, Coll. Africa-Europe Group for Interdisciplinary Studies, Vol. 12, Leiden, Brill.

Boiral P., Lanteri J.-F., Olivier de Sardan J.-P. (eds.), 1985, Paysans, Experts et Chercheurs en Afrique Noire. Sciences Sociales et Développement Rural, Paris, Karthala, CIFACE.

Carmona A.R., 2008, El Proyectorado: Bolivia tras 20 Años de Ayuda Externa, La Paz, Intermón Oxfam Editorial.

Chambers R., Pacey A., Thrupp L.A. (eds.), 1989, Farmers First. Farmer Innovation and Agricultural Research, London, Intermediate Technology Publications.

Chauveau J.-P., 1982a, “L'image de l'Agriculture Baule (Côte-d'Ivoire) et les Développeurs: Référent Précolonial et Réalités Historiques”, Économie Rurale, no. 147(1), pp. 95-101.

Chauveau J.-P., 1982b, "Pour une Sociologie Historique du Développement", Coll. Institutions et Pratique du Développement, Paris, ORSTOM (Département SUD).

Chauveau J.-P., 1994, "Participation Paysanne et Populisme Bureaucratique. Essai d'Histoire et de Sociologie de la Culture du Développement", in J.-P. Jacob and P. Lavigne Delville (eds.), Les Associations Paysannes en Afrique: Organisation et Dynamiques, Paris, Karthala, APAD, IUED, pp. 25-60. Chauveau J.-P., Dozon J.-P., Richard J., 1981, “Histoires de Riz, histoires d'Igname: Le Cas de la Moyenne Côte d'Ivoire”, Africa, no. 51(2), pp. 621-658.

CNRST, ORSTOM, 1979, Maîtrise de l'Espace Agraire et Développement en Afrique Tropicale. Logique Paysanne et Rationalité Technique, Ougadougou, Paris, Centre National de la Recherche Scientifique et Technique de la Haute-Volta, Office de la Recherche Scientifique et Technique Outre-Mer.

Copans J., 1975, Anthropologie et Impérialisme: Textes, Paris, F. Maspero.

Copans J., 2009a, “L’Anthropologie de l'Aide Humanitaire et du Développement Est Bien une Anthropologie Sociale Globale!", in L. Atlani Duault and L. Vidal (eds.), Anthropologie de l'Aide Humanitaire et du Développement. Des Pratiques aux Savoirs, des Savoirs aux Pratiques, Paris, Armand Colin, pp. 11-15.

Copans J., 2009b, “Un Développement Sans Acteurs Mais Non Sans Politique. La Difficile Empiricité d'un Engagement Anti-Impérialiste”, Journal des Anthropologues, no. 118-119, pp. 65-88.

Copans J., 2016, “L'Afrique Noire A-t-elle Besoin du Développement (de l'Anthropologie) ou au Contraire d'une Anthropologie (du Développement)?", in M. Lafay, F. Le Guennec-Coppens and E. Coulibaly (eds.), Regards Scientifiques sur l'Afrique depuis les Indépendances, Paris, Karthala, Société des Africanistes, pp. 377-396.

Couty P., Durand M.-H., Gastellu J.-M. et al. (eds.), 1985, Approche Anthropologique et Recherche Économique à l'ORSTOM, Coll. Colloques et Séminaires, Paris, ORSTOM.

Couty P., Pontié G., Robineau C. (eds.), 1983, Le Développement: Idéologies et Pratiques. Actes du Séminaire Interdisciplinaire de l'ORSTOM (1978-1981), Paris, ORSTOM.

Crewe E., Axelby R., 2013, Anthropology and Development: Culture, Morality and Politics in a Globalised World, Cambridge, Cambridge University Press.

Dozon J.-P., 1979, “Impasses et Contradictions d'une Société de Développement: L’Exemple de l'Opération Riziculture Irriguée en Côte d'Ivoire", Cahiers ORSTOM Sciences Humaines, no. XVI(1-2), pp. 37-58. 
Dumont R., 1935, La Culture du Riz dans le Delta du Tonkin. Étude et Propositions d'Amélioration des Techniques Traditionnelles de Riziculture Tropicale, Paris, Société d'Éditions Géographiques, Maritimes et Coloniales.

Elwert G., Bierschenk T., 1988, “Development Aid as an Intervention in Dynamics Systems”, Sociologia Ruralis, no. 28(2-3), pp. 99-112.

Evans-Pritchard E.E., 1946, “Applied Anthropology”, Africa, no. 16(2), pp. 92-98.

Evers H.D., Schiel T., 1988, Strategische Gruppen. Theoretische Vergleichende Untersuchungen über Staat, Bürokratie und Klassenbildung, Berlin, Reimer.

Eyben R., 2011, “The Sociality of International Aid and Policy Convergence”, in D. Mosse (ed.), Adventures in Aidland. The Anthropology of Professionals in International Development, London, Berghahn, pp. 139-160.

Fresia M., 2018, "Enquêter au Coeur de la Bureaucratie Transnationale de l'Asile. Réflexions sur les Rapports Ambivalents entre le HCR et les Milieux Académiques", in M. Fresia and P. Lavigne Delville (eds.), Au Coeur des Mondes de l'Aide Internationale. Regards et Postures Ethnographiques, Paris, Marseille, Montpellier, Karthala, IRD, APAD, pp. 41-74.

Fresia M., Lavigne Delville P. (eds.), 2018a, Au Cœur des Mondes de l'Aide Internationale. Regards et Postures Ethnographiques, Paris, Marseille, Montpellier, Karthala, IRD, APAD.

Fresia M., Lavigne Delville P., 2018b, “Les de l'Aide et Leurs Pratiques. Regards Ethnographiques sur des Fragments d'une Gouvernance Globalisée", in M. Fresia and P. Lavigne Delville (eds.), Au Cour des Mondes de l'Aide Internationale. Regards et Postures Ethnographiques, Paris, Marseille, Montpellier, Karthala, IRD, APAD, pp. 9-40.

Hagberg S., 2011, “Trajectoires de l'Anthropologie du Développement à la Suédoise”, Ethnologie Française, no. 41(3), pp. 509-519.

Hagberg S., Kibora L., Ouattara F. et al., 2015, “Au Coeur de la Révolution Burkinabè”, Anthropologie \& Développement, no. 42, pp. 199-224.

Hagberg S., Körling G., 2012, "Socio-Political Turmoil in Mali: The Public Debate Following the 'Coup d'État' on 22 March 2012”, Africa Spectrum, no. 47(2-3), pp. 111-125.

Hagberg S., Ouattara F. (eds.), 2012, Engaging Anthropology for Development and Social Change, Bulletin de l'APAD no. 34-36, Berlin, LIT, APAD.

Hagberg S., Widmark C., 2009, Ethnographic Practice and Public Aid: Methods and Meanings in Development Cooperation, Coll. Uppsala Studies in Cultural Anthropology, Uppsala, Acta Universitatis Upsaliensis.

Hobart M. (ed.), 1993, An Anthropological Critique of Development. The Growth of Ignorance, London, EIOS, Routledge.

Khon Kaen U., 1987, Proceedings of the 1985 International Conference on Rapid Rural Appraisal, Rural Systems Research and Farming Systems Research Projects, Thailand, Khon Kaen.

Lame D. de (ed.), 2000, Genre et Développement, Bulletin de l'APAD no. 20, Berlin, LIT, APAD.

Lavigne Delville P., 2007, “À la Recherche du Chaînon Manquant. Construire des Articulations entre Recherche en Sciences Sociales et Pratique du Développement”, in T. Bierschenk, G. Blundo, Y. Jaffré et al. (eds.), Une Anthropologie entre Rigueur et Engagement. Essais Autour de l'Oeuvre de Jean-Pierre Olivier de Sardan, Leiden, Paris, APAD, Karthala, pp. 127-150. 
Lavigne Delville P., 2012, “Affronter l'Incertitude?: Les Projets de Développement à ContreCourant de la 'Révolution du Management de Projet”, Revue Tiers Monde, no. 211, pp. 153-168.

Lavigne Delville P., 2016, "Pour une Socio-Anthropologie de l'Action Publique dans les Pays ‘sous Régime d'Aide"', Anthropologie \& Développement, no. 45, pp. 33-64.

Lentz C., 1988, "Why the Most Incompetent are on the Village Council: Development Projects in an Indian Village in Ecuador", Sociologia Ruralis, no. 28(2-3), pp. 199-215.

Lewis D., Mosse D., 2006, Development Brokers and Translators. The Ethnography of Aid and Agencies, Bloomfield, Kumarian Press.

Li T.M., 2007, The Will To Improve. Governmentality, Development, and the Practice of Politics, Durham, Duke University Press.

Li T.M., 2013, “Les Engagements Anthropologiques vis-à-vis du Développement”, Anthropologie \& Développement, no. 37-38-39, pp. 241-256.

Li T.M., 2020, Agir pour les Autres. Gouvernementalité, Développement et Pratique du Politique, Coll. Hommes et Sociétés, Paris, Montpellier, Karthala, APAD.

Long N., 1977, An Introduction to the Sociology of Rural Development, London, Tavistock.

Long N., 1989, Encounters at the Interface. A Perspective in Social Discontinuities in Rural Development, Wageningen, Wageningen Agricultural University.

Long N., Long A., 1992, Battlefields of Knowledge. The Interlocking of Theory and Practice in Social Research and Development, London, EIDOS, Routledge.

Mair L., 1971, Anthropology and Social Change, London, University of London, Athlone Press.

Malinowski B., 1929, "Practical Anthropology”, Africa, no. 2(1), pp. 22-38.

Mathieu M., 1996, “Conférence Internationale de Pékin..., Ôtez-moi d'un doute!”, Bulletin de l'APAD, no. 11, https://doi.org/10.4000/apad.841

Mathieu M., 2012, “'L’Auxiliaire': Une Approche Empirique du Rôle de l'Anthropologue dans des Projets de Coopération au Développement", Bulletin de l'APAD, no. 34-36, pp. 147-174.

Mosse D., 2005, Cultivating Development. An Ethnography of Aid Policy and Practice, London, Pluto Press.

Mosse D. (ed.), 2011, Adventures in Aidland. The Anthropology of Professionals in International Development, Coll. Studies in Public and Applied Anthropology, Vol. 6, London, Berghahn.

Mosse D., Lewis D., 2005, The Aid Effect: Giving and Governing in International Development, London, Pluto Press.

Olivier [de Sardan] J.-P., 1975, “Afrique: Qui Exploite Qui? (À Propos de Samir Amin et des Bourgeoisies d'État Africaines)”, Les Temps Modernes, no. 346, pp. 1506-1551.

Olivier de Sardan J.-P., 1991a, “La Préhistoire de l'APAD”, Bulletin de l'APAD, no. 1, https://doi.org/ 10.4000/apad.324

Olivier de Sardan J.-P., 1991b, "L'Anthropologie du Changement Social et du Développement Comme Ambition Théorique?”, Bulletin de l'APAD, no. 1, pp. 7-11.

Olivier de Sardan J.-P., 1995, Anthropologie et Développement. Essai en Anthropologie du Changement Social, Paris, APAD, Karthala.

Olivier de Sardan J.-P., 2004, “Le Chaînon Manquant”, Courrier de la Planète, no. 74, pp. 36-40. 
Olivier de Sardan J.-P., 2007, “De la Nouvelle Anthropologie Du Développement à la SocioAnthropologie des Espaces Publics Africains”, Revue Tiers Monde, no. 191(3), pp. 543-552. Olivier de Sardan J.-P., 2021, La Revanche des Contextes. Des Mésaventures de l'Ingénierie Sociale, en Afrique et Au-Delà, Paris, Karthala.

Olivier De Sardan J.-P., Paquot E., 1991, D’un Savoir à l'Autre. Les Agents de Développement comme Médiateurs, Paris, GRET, Ministère de la Coopération.

Pillot D., 1990, "Francophone and Anglophone Farming Systems Research: Similarities and Differences", in G. Trébuil (ed.), Farming Systems Research and Development in Thailand. Illustrated Methodological Considerations and Recent Advances, Haad Yai, Prince of Songkla University, pp. 3-24.

Pommerolle M.-E., 2008, “La Démobilisation Collective au Cameroun: Entre Régime Postautoritaire et Militantisme Extraverti”, Critique Internationale, no. 40(3), pp. 73-94.

Quarles Van Ufford P., Kumar Giri A. (eds.), 2003, A Moral Critique of Development. In Search of Global Responsibilities, London, New York, Routledge.

Quashie H., 2016, “Débuter sa Carrière Professionnelle en Afrique. L'Idéal d'Insertion Sociale des Volontaires Français à Dakar et Antananarivo (Sénégal et Madagascar)", Cahiers d'Études Africaines, no. 221(1), pp. 53-80.

Quashie H., 2020, “L'Expatriation de la Recherche Française en Afrique Subsaharienne: Distinctions Raciales et Épistémologies Scientifiques (Sénégal, Madagascar, Bénin)”, Histoire de la Recherche Contemporaine. La Revue du Comité pour l'Histoire du CNRS, no. 8(2), pp. 208-229.

Reikat A., 2012, "Jeux de Rôles. Ou: l'"Intermédiaire Professionnel" A-t-il une Place dans le Système de l'Aide au Développement?", Bulletin de l'APAD, no. 34-36, pp. 175-192.

Richards P., 1985, Indigenous Agricultural Revolution, London, Hutchinson.

Risse T., 2013, “Governance under Limited Sovereignty”, in M. Finnemore and J. Goldstein (eds.), Back to Basics: State Power in a Contemporary World, Oxford, Oxford University Press, pp. 78-104.

Schlippe P. de, 1956, Shifting Cultivation in Africa: The Zande System of Agriculture, London, Routledge \& Kegan Paul London.

Venot J.-P., Veldwisch G.J. (eds.), 2017, “Mythes Sociotechniques et Développement”, Anthropologie \& Développement, no. 46-47, pp. 27-48.

Vidal L., 2009, Faire de l'Anthropologie. Santé, Science et Développement, Coll. Terrains Anthropologiques, Paris, La Découverte.

\section{NOTES}

1. The Bulletin de l'APAD, which became Anthropologie \& Développement in 2013, starting with nos. 37,38 and 39 .

2. The film is available on Vimeo: https://vimeo.com/270129069 (consulted on 16 September 2021).

3. This number has been prepared thanks to the involvement of the editorial board, as well as an ad hoc committee whose members include Sophie Andreetta, Sylvie Ayimpam, Laurence Boutinot, Marie Deridder, Nehara Feldman, Philippe Lavigne Delville and Alexis Roy.

4. We would like to thank Thomas Bierschenk, Giorgio Blundo, Jean-Pierre Chauveau, Pascale Maizi, Jean-Pierre Olivier de Sardan and Fatoumata Ouattara for their comments on and contributions to this interpretation of APAD's history. 
5. See T. Bierschenk (2009) for a perspective on North America.

6. Amélioration des méthodes d'investigation en milieu rural et informel [Improvements in investigation methods in the rural and informal environment]: a pluridisciplinary network established under the aegis of Gérard Winter, under the dual tutelage ofORSTOM (which provide the essential part of the contributions) and INSEE.

7. See a brief history of the topics on the APAD website: https://apad-association.org/ lassociation/

8. The idea of this section was suggested by Thomas Bierschenk at a meeting of the editorial board for the preparation of this issue. We thank him for it. See also his article (Bierschenk, 2009), in which he proposed a socio-analysis by APAD over ten years ago.

9. Philippe Lavigne Delville was still a doctoral student at EHESS when APAD gave him responsibility for the 1992 symposium on peasent organisations, with Jean-Pierre Jacob. Giorgio Blundo, who organised one of the plenary conferences, was also a doctoral student.

10. A position that has inspired a debate within anthropology. See, for example, T.M. Li (2013).

11. It had been suggested by Giorgio Blundo at the Yaoundé general meeting in 2005, but it was clearly too early.

12. This was reinforced by the fact that the film was shot in Niamey, with the people who were attending the summer school. We had planned to interview more people, including Mirjam De Bruijn, but did not have the resources to fund the necessary travel.

\section{AUTHORS}

PHILIPPE LAVIGNE DELVILLE

IRD, UMR SENS, Montpellier; philippe.lavignedelville[at]ird.fr

\section{ALEXIS ROY}

CNRS, UMR IMAF, Aubervilliers; alexis.roy[at]cnrs.fr 